Jurnal Sain Veteriner, Vol. 37. No. 1. Juni 2019, Hal. 27-33

DOI : $10.22146 /$ jsv.40375

ISSN 0126-0421 (Print), ISSN 2407-3733 (Online)

Tersedia online di https://jurnal.ugm.ac.id/jsv

\title{
Isolasi, Identifikasi, dan Serotyping Avibacterium paragallinarum dari Ayam Petelur Komersial yang Menunjukkan Gejala Snot
}

\section{Isolation, Identification, and Serotyping Avibacterium paragallinarum from Commercial Layer with Snot Symptoms}

\author{
Elisabet Tangkonda ${ }^{1^{*}}$, Charles Rangga Tabbu $^{2}$, Agnesia Endang Tri Hastuti Wahyuni ${ }^{3}$ \\ ${ }^{1}$ Laboratorium Mikrobiologi, Fakultas Kedokteran Hewan, Universitas Nusa Cendana Kupang \\ ${ }^{2}$ Laboratorium Patologi, Fakultas Kedokteran Hewan, Universita Gadjah Mada Yogyakarta \\ ${ }^{3}$ Laboratorium Mikrobiologi Fakultas Kedokteran Hewan Universitas Gadjah Mada Yogyakarta \\ *Email: tangkonda.e@staf.undana.ac.id
}

Naskah diterima : 1 November 2018, direvisi : 22 Januari 2019, disetujui : 29 Januari 2019

\begin{abstract}
Infectious coryza (snot) is one of acute respiratory disease in breeders, layers, and broilers caused by Avibacterium paragallinarum (Av. paragallinarum). This disease is very harmful because of its cause decrease in egg production and high morbidity. Snot incident in Indonesia still is reported. Vaccination is one of the best preventive measures, but reports about Av. paragallinarum serotype at the field so lack so that the correspondence between serotype Av. paragallinarum in the field to those used for vaccination is unknown. Av. paragallinarum has strains with different antigenicity and until now known three serotypes there are serotypes A, B and C. Serotypes A and C are pathogenic then serotypes B. The purpose of this study was to isolate, identify and to determine the serotype of $A v$. paragallinarum from the commercial layer that showing symptoms of snot. Samples were taken from layer which showed symptoms of snot (nasal foul smelling exudate, infra-orbital and wattle swelling, conjunctivitis, and snoring) from some layer farms. Samples were cultured on chocolate agar and then incubated in a candle jar at $37{ }^{\circ} \mathrm{C}$ for $18-24$ hours. Bacteria colony and cell morphology were observed and performed biochemical tests (catalase, oxidase, urease, indole, and fermentation of carbohydrates) in suspected colonies. Serotypes test was conducted using plate agglutination test (PAT). This study revealed 4 isolates Av. paragallinarum with 2 isolates are serotype B and 2 other are serotype $C$.
\end{abstract}

Key words: Avibacterium paragallinarum; identification; infectious coryza; isolation; serotype

\begin{abstract}
Abstrak
Infectious coryza (snot) adalah salah satu penyakit pernapasan atas pada breeder, layer dan broiler yang disebabkan oleh Avibacterium paragallinarum (Av. paragallinarum). Penyakit ini sangat merugikan karena mengakibatkan penurunan produksi telur dan morbiditas yang tinggi. Kejadian snot di Indonesia sampai sekarang masih terus dilaporkan. Pemberian vaksinasi adalah salah satu tindakan pencegahan terbaik, namun laporan tentang Av. paragallinarum dan jenis serotipe yang ada di lapangan masih sedikit, sehingga kesesuaian antara jenis serotipe $A v$. paragallinarum di lapangan dengan yang digunakan untuk vaksinasi belum diketahui. Av. paragallinarum memiliki strain dengan antigenisitas yang berbeda dan hingga saat ini diketahui tiga serotipe yaitu serotipe A, B dan C. Serotipe A dan $\mathrm{C}$ bersifat patogen sedangkan serotipe B kurang patogen. Tujuan penelitian ini adalah untuk mengisolasi, mengidentifikasi dan menentukan serotipe Av. paragallinarum dari ayam petelur komersial yang menunjukkan gejala snot. Sampel diambil dari ayam yang menunjukkan gejala snot (eksudat berbau busuk dari mata dan hidung, kebengkakan infra orbital dan pial, konjungtivitis, dan adanya suara ngorok halus) dari beberapa peternakan layer. Sampel dikultur pada media agar coklat kemudian diinkubasi dalam candle jar pada suhu $37{ }^{\circ} \mathrm{C}$ selama $18-24$ jam. Morfologi koloni dan sel bakteri diamati dan dilakukan uji biokimia (katalase, oksidase, urease, indol, dan fermentasi karbohidrat) pada koloni yang diduga Av. paragallinarum. Uji serotipe dilakukan dengan metode plate agglutination test (PAT). Penelitian ini mendapat hasil 4 isolat Av. paragallianrum dengan 2 isolat merupakan serotipe B dan 2 lainnya serotipe $\mathrm{C}$.
\end{abstract}

Kata kunci: Avibacterium paragallinarum; identifikasi; infectious coryza; isolasi; serotipe 
Elisabet Tangkonda, et. al.

\section{Pendahuluan}

Infectious coryza (snot) adalah penyakit pernapasan pada ayam, yang disebabkan oleh Avibacterium paragallinarum (Av. paragallinarum) yang sebelumnya dikenal dengan nama Haemophilus paragallinarum (Blackall et al., 2005). Penyakit ini bersifat sangat infeksius dan menyerang saluran pernapasan bagian atas dan berlangsung akut sampai kronis. Secara umum snot adalah penyakit yang menyebabkan morbiditas tinggi, tetapi mortalitas rendah. (Yamamoto, 1984; Blackall, 1999; Droual et al., 1990; Blackall et al., 2005; El-sawah et al., 2012).

Penyakit ini mempunyai dampak ekonomik yang merugikan pada industri perunggasan di berbagai negara di dunia meliputi Amerika, Uni Eropa, Australia, Afrika dan Asia. Dampak ekonomi yang tinggi diakibatkan meningkatnya jumlah ayam yang diafkir, penurunan produksi telur, penurunan berat badan, hambatan pertumbuhan, peningkatan biaya pengobatan, dan sejumlah mortalitas (Droual et al., 1990; Blackall, 1999). Di Indonesia, penyakit ini dapat ditemukan di berbagai daerah pada ayam petelur, ayam bibit (parent stocks, PS), dan ayam pedaging.

Diagnosis sangkaan terhadap snot dapat didasarkan atas gejala klinis dan perubahan patologi yang ditimbulkan oleh penyakit ini. Diagnosis akhir dapat dilakukan dengan isolasi dan identifikasi bakteri dari kasus snot pada stadium akut yaitu antara 1-7 hari pasca infeksi (Tabbu, 2000). Uji serologis dapat dilakukan untuk menentukan serotipe agen penyebab snot. Av. paragallinarum memiliki strain dengan antigenisitas yang berbeda, dan sampai saat ini terdapat tiga serotipe yang telah dikarakterisasi, yaitu serotipe A, B, dan C. Serotipe A dan serotipe C dikenal sebagai serotipe yang virulen, tetapi sekarang ditemukan bahwa Serotipe B juga memiliki peranan dalam kejadian penyakit snot namun tidak menunjukkan gejala klinis yang signifikan
(Yamaguchi et al., 1990; Tabbu, 2000).

Penyakit ini dapat dicegah dengan pemberian vaksin in aktif pada ayam petelur atau parent stocks, pada fase grower dan menjelang produksi telur. Sehubungan dengan kenyataan bahwa vaksin snot hanya memberikan kekebalan silang yang minimal diantara berbagai serotipe Av. paragallinarum, maka vaksin yang terbaik seharusnya bersifat otogenus atau homolog dengan kuman penyebab snot yang terdapat di lapangan. Dalam hal ini menggunakan vaksin snot yang mempunyai serotipe yang sama atau serotipe yang dapat mengadakan reaksi silang dengan serotipe Av. paragallinarum yang berada di lapangan. Informasi jenis serotipe yang ada di lapangan dapat diketahui dengan melakukan isolasi, identifikasi dan uji serotipe terhadap isolat yang berasal dari ayam layer yang menunjukkan gejala snot.

Cabrera et al. (2011) melakukan serotyping hemagglutinin terhadap isolat Av. paragallinarum dari Ecuador dengan menggunakan metode Scheme hemagglutinin dengan hasil 17 dari total 28 isolat adalah serovar A-3, 5 isolat adalah B-1, 5 isolat C-1, dan satu isolat tidak teridentifikasi. Chukiatsiri et al. (2012) melakukan penelitian tentang identifikasi, sensitifitas antimikrobial dan virulensi dari isolat $A v$. paragalinarum asal ayam di Thailand dengan hasil 10 isolat adalah serovar A, lima isolat serovar B, tiga isolat serovar C.

Penelitian yang dilakukan oleh Poernomo et al. (2000), tentang karakterisasi isolat Haemophilus paragallinarum yang berasal dari Indonesia membuktikan bahwa di Indonesia terdapat tiga serotipe Haemophilus paragallinarum, yaitu serotipe A, B, dan C. Wahyuni et al. (2011) mendapat hasil isolasi dan identifikasi Av. paragallinarum serotipe C.

Penelitian tentang serotipe $A v$. paragallinarum di Indonesia belum banyak dilaporkan sehingga sebaran jenis serotipe di Indonesia belum 
banyak diketahui. Berdasarkan penelitian yang dilakukan oleh para peneliti sebelumnya, maka masih dibutuhkan penelitian lanjutan untuk mendapatkan pola sebaran jenis serotipe dari Av. paragallinarum di lapangan yang berguna untuk mendukung keberhasilan program vaksinasi.

Tujuan dari penelitian ini adalah untuk mengisolasi, mengidentifikasi dan serotyping $A v$. paragallinarum dari ayam petelur komersial yang menunjukkan gejala snot.

\section{Materi dan Metode}

Penelitian ini menggunakan 12 sampel ayam yang menunjukkan gejala snot, antisera spesifik $A v$. paragallinarum serotipe $\mathrm{A}, \mathrm{B}$, dan $\mathrm{C}$, media agar coklat, media semi solid, media urea, media pepton, hidrogen proksida $\left(\mathrm{H}_{2} \mathrm{O}_{2}\right)$, kertas oksidase, media gula.

\section{Isolasi Bakteri}

Bakteri diisolasi dari sinus infraorbital layer yang menunjukkan gejala snot dan dikultur pada agar coklat secara aseptis dengan metode T-streak . Media diinkubasi di dalam candle jar pada suhu $37{ }^{\circ} \mathrm{C}$ selama 18-24 jam. Pertumbuhan dan morfologi koloni diamati setelah 24 jam.

\section{Identifikasi Bakteri}

Koloni bakteri diindentifikasi dengan mengamati karakter pertumbuhan koloni dan mengamati karakter sel bakteri melalui pengecatan Gram. Morfologi Av. paragallinarum kecil, bulat, transparan dan tampak seperti tetesan embun, bersifat kokobasil Gram negatif (Blackall dan Soriano, 2008; El-Ghany, 2011; Priya et al., 2012).

\section{Uji biokimia}

Uji biokimia dilakukan terhadap koloni yang menunjukkan karakter morfologi Av. paragallinarum.
Uji biokimia yang dilakukan antara lain uji katalase, uji oksidasi, uji indol, uji urease, dan uji fermentasi karbohidrat. Av. paragallinarum bersifat katalase negatif, oksidase negatif, indol negatif, fermentasi glukosa, laktosa, manitol, sukrosa dan sorbitol (ElGhany, 2011; Priya et al., 2012).

\section{Uji serologis}

Uji serologis dilakukan berdasarkan skema Page dengan metode plat aglutinasi menggunakan antisera spesifik (Page, 1962). Menurut skema Page terdapat 3 serotipe Av. paragallinarum, yaitu serotipe A, B dan C.

\section{Hasil dan Pembahasan}

Avibacterium paragallinarum telah berhasil diisolasi sebanyak 4 isolat dari 12 sampel ayam. Gejala klinis yang ditunjukkan oleh 12 ayam sampel yaitu 7 ekor menunjukkan kebengkakan di daerah kepala, 8 ekor menunjukkan adanya leleran hidung yang berbau busuk, dan 3 ekor menunjukkan adanya kebengkakan kepala dan leleran hidung yang berbau busuk (Tabel 1). Blackall dan Matsumoto (2003) menyatakan gejala klinis yang ditunjukkan oleh ayam petelur yang mengalami infeksi snotadalah kebengkakakan kepala, leleran hidung, konjungtivitis, dan penurunan produksi telur. Namun demikian, tidak semua ayam yang menunjukkan gejala klinis seperti ini terinfeksi $A v$. paragallinarum. Diantara 12 swab sampel hanya ditemukan 4 sampel yang positif Av. paragallinarum, yaitu ayam dengan kode A2, A8, A11 dan A12 (Tabel1).

Berdasarkan karakter morfologi, dari 12 koloni ditemukan hanya 6 koloni yang menunjukkan karakter morfologik Av. paragallinarum (Tabel 1) yaitu koloni yang berukuran kecil, bulat, transparan dengan permukaan dan tepi koloni halus dan tampak seperti tetesan embun (Gambar 1) sama dengan yang ditemukan oleh peneliti sebelumnya (Wahyuni et al., 2011; Priya et al., 2012). 
Elisabet Tangkonda, et. al.

Tabel 1. Hasil Pengamatan dan Pengujian Sampel Layer yang Menunjukkan Gejala Snot

\begin{tabular}{|c|c|c|c|c|c|c|c|c|c|c|c|c|c|c|c|c|c|c|c|c|c|c|}
\hline \multirow[b]{2}{*}{ Kode } & \multirow[b]{2}{*}{ Asal } & \multirow{2}{*}{$\begin{array}{l}\text { Umur } \\
(\mathrm{mgg})\end{array}$} & \multirow[b]{2}{*}{$\mathrm{B}$} & \multirow[b]{2}{*}{$\mathrm{L}$} & \multicolumn{2}{|c|}{ Warna } & \multicolumn{2}{|c|}{ Bentuk } & \multicolumn{2}{|c|}{ Bentuk } & \multicolumn{2}{|c|}{ Sifat } & \multicolumn{9}{|c|}{ Karakter Biokimia } & \multirow[b]{2}{*}{ Serotipe } \\
\hline & & & & & $\mathrm{T}$ & $\mathrm{P}$ & $\mathrm{Bl}$ & I & $\mathrm{CC}$ & $\mathrm{C}$ & $\begin{array}{c}\text { Gram } \\
-\end{array}$ & $\begin{array}{c}\text { Gram } \\
+\end{array}$ & $\mathrm{K}$ & $\mathrm{O}$ & $\mathrm{U}$ & I & G & $\mathrm{Lk}$ & M & $\mathrm{Su}$ & So & \\
\hline $\mathrm{A} 1$ & Sleman & 13 & $\mathrm{v}$ & - & - & $\mathrm{v}$ & $v$ & - & $\mathrm{v}$ & $\mathrm{v}$ & $\mathrm{v}$ & $\mathrm{v}$ & $\mathrm{Tl}$ & $\mathrm{Tl}$ & $\mathrm{Tl}$ & $\mathrm{Tl}$ & $\mathrm{Tl}$ & $\mathrm{Tl}$ & $\mathrm{Tl}$ & $\mathrm{Tl}$ & $\mathrm{Tl}$ & $\mathrm{Tl}$ \\
\hline A2 & Sleman & 13 & $\vee$ & - & v & - & V & - & v & - & v & - & - & - & - & - & + & + & + & + & + & B \\
\hline A3 & Jombang & 13 & $v$ & v & - & $\mathrm{v}$ & - & $\vee$ & v & - & 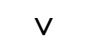 & - & $\mathrm{Tl}$ & $\mathrm{Tl}$ & $\mathrm{Tl}$ & $\mathrm{Tl}$ & $\mathrm{Tl}$ & $\mathrm{Tl}$ & $\mathrm{T} 1$ & $\mathrm{Tl}$ & $\mathrm{Tl}$ & $\mathrm{Tl}$ \\
\hline A4 & Jombang & 13 & v & v & - & $\mathrm{V}$ & - & $v$ & v & - & v & - & $\mathrm{Tl}$ & $\mathrm{Tl}$ & $\mathrm{Tl}$ & $\mathrm{Tl}$ & $\mathrm{Tl}$ & $\mathrm{Tl}$ & $\mathrm{Tl}$ & $\mathrm{Tl}$ & $\mathrm{Tl}$ & $\mathrm{Tl}$ \\
\hline A5 & Jombang & 13 & V & $v$ & - & $\mathrm{V}$ & - & $v$ & v & - & v & - & $\mathrm{Tl}$ & $\mathrm{Tl}$ & $\mathrm{Tl}$ & $\mathrm{Tl}$ & $\mathrm{Tl}$ & $\mathrm{Tl}$ & $\mathrm{Tl}$ & $\mathrm{Tl}$ & $\mathrm{Tl}$ & $\mathrm{Tl}$ \\
\hline A6 & Magelang & 17 & v & - & - & $\mathrm{V}$ & - & v & v & - & v & - & $\mathrm{Tl}$ & $\mathrm{Tl}$ & $\mathrm{Tl}$ & $\mathrm{Tl}$ & $\mathrm{Tl}$ & $\mathrm{T} 1$ & $\mathrm{Tl}$ & $\mathrm{Tl}$ & $\mathrm{Tl}$ & $\mathrm{Tl}$ \\
\hline A7 & Magelang & 17 & v & - & - & $\mathrm{v}$ & v & - & v & - & v & - & $\mathrm{Tl}$ & $\mathrm{Tl}$ & $\mathrm{Tl}$ & $\mathrm{Tl}$ & $\mathrm{Tl}$ & $\mathrm{Tl}$ & $\mathrm{Tl}$ & $\mathrm{Tl}$ & $\mathrm{Tl}$ & $\mathrm{Tl}$ \\
\hline A8 & Sleman & 8 & - & V & V & - & v & - & v & - & v & - & - & - & - & - & + & + & + & + & + & B \\
\hline A9 & Sleman & 8 & - & v & $v$ & - & $v$ & - & v & - & v & - & + & + & - & - & + & + & + & + & + & $\mathrm{Tl}$ \\
\hline A10 & Sleman & 8 & - & v & v & - & $\mathrm{v}$ & - & v & - & $v$ & - & - & - & - & - & + & + & + & + & + & $\mathrm{Tl}$ \\
\hline A11 & Klaten & 24 & - & $v$ & $v$ & - & $v$ & - & v & - & v & - & - & - & - & - & + & + & + & + & + & $\mathrm{C}$ \\
\hline A12 & Klaten & 24 & - & v & v & - & $\mathrm{V}$ & - & V & - & v & - & - & - & - & - & + & + & + & + & + & $\mathrm{C}$ \\
\hline
\end{tabular}

keterangan:
B: Bengkak
Bl: Bulat
$\mathrm{K}$ : Katalase
G: Glukosa
So: Sorbitol
L: Leleran
I: Irreguler
$\mathrm{O}$ : Oksidase
Lk: Laktosa
TL:Tidak dilakukan

P:Putih Keabuan CC: Kokobasil U: Urease M: Maltosa V: Menunjukkan hasil
T: Transparan
C: kokus
I: Indol
$\mathrm{Su}$ : Sukrosa -: Tidak menunjukkan hasil

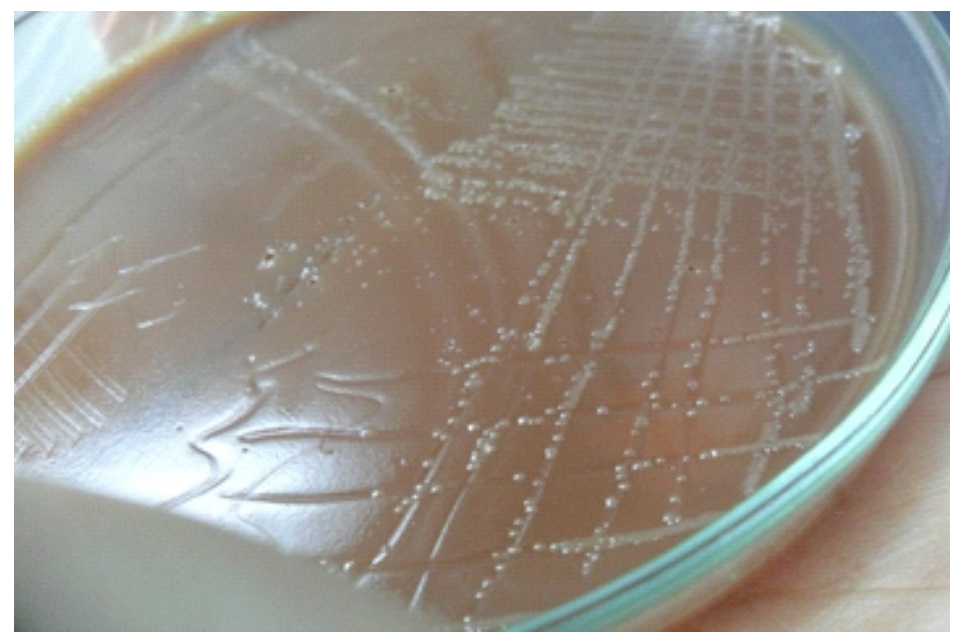

Gambar 1. Koloni Av. paragallinarum yang berbentuk bulat, kecil seperti $\quad$ tetesan embun $(\rightarrow)$

Hasil pewarnaan Gram, 11 koloni dugaan bersifat Gram negatif dengan bentuk sel kokobasil, satu koloni bersifat heterogen yaitu morfologi sel bakteri yang teramati adalah Gram positif dan Gram negatif dengan bentuk sel kokobasil dan kokus. Hasil pewarnaan Gram dari koloni dugaan yang bersifat Gram negatif dan berbentuk kokobasil (Gambar 2) sama dengan hasil yang ditemukan oleh peneliti sebelumnya yang menyatakan bahwa isolat dugaan $A v$. paragallinarum bersifat Gram negatif dengan sel bakteri berbentuk kokobasil (Priya et al., 2012).

Hasil identifikasi dengan uji biokimia menunjukkan 5 isolat memiliki karakteristik biokimia yang mengarah ke sifat biokimia Av. paragallinarum yaitu tidak memproduksi indol, katalase negatif, oksidasi negatif, urease negatif, memfermentasi glukosa, laktosa, manitol, sukrosa, dan sorbitol (Tabel 1). 


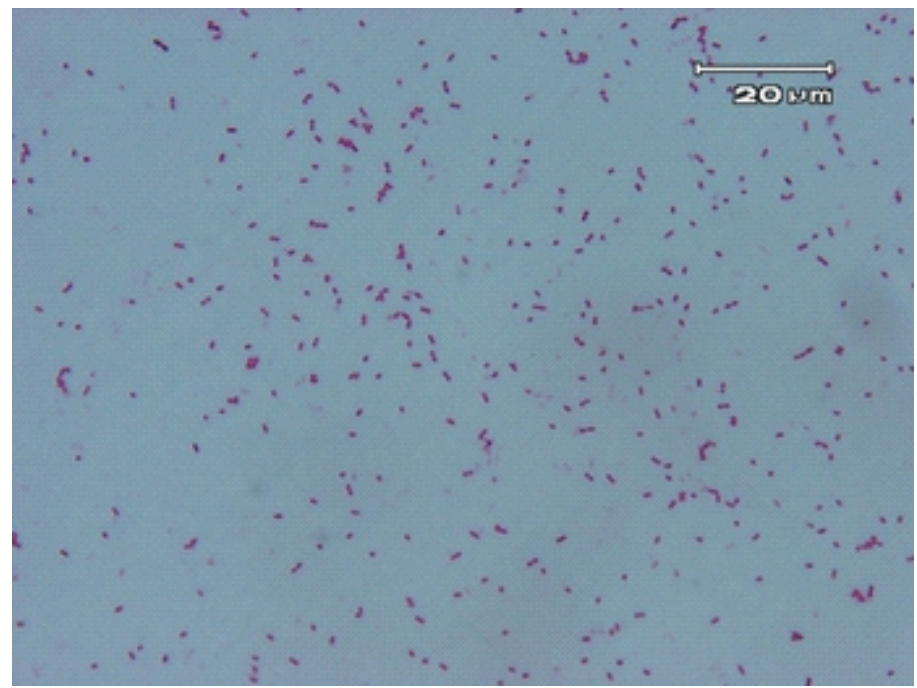

Gambar 2. Gambaran mikroskopik sel bakteri dugaan Av. Paragallinarum yang berbentuk kokobasil $(\rightarrow)$

Sifat-sifat biokimia yang diperoleh pada penelitian ini menunjukkan hasil yang sama dengan yang dilakukan peneliti sebelumnya (Poernomo et al., 2000; Chukiatsiri et al., 2012) yang melaporkan bahwa karakter biokimia $A v$. paragallinarum yang ditemukan pada penelitiannya adalah katalase negatif, oksidase negatif, indol negatif, $\mathrm{H}_{2} \mathrm{~S}$ negatif, memfermentasi glukosa, laktosa, sukrosa, dan manitol.

Hasil uji serotipe mendapatkan 4 isolat yang teridentifikasi Av. paragallinarum sedangkan satu isolat tidak teridentifikasi sebagai $A v$. paragallinarum. Kasus ini bisa terjadi karena isolat referensi yang digunakan hanya tiga referensi yaitu referensi serotipe $\mathrm{A}, \mathrm{B}$, dan $\mathrm{C}$ dan metode yang digunakan berdasarkan klasifikasi Page, yang hanya mengklasifikasi Av. paragallinarum dalam 3 serotipe, sedangkan sampai saat ini di katakan ada 9 serovar $A v$. paragallinarum yang telah berhasil diidentifikasi berdasarkan klasifikasi Kume (Roodt, 2009). Klasifikasi dari tiga jenis serotipe Av. paragallinarum didasarkan pada struktur antigen dari masing-masing serotipe (Sawata, et al.,1979). Penelitian di Thailand menemukan 10 isolat serotipe A, 5 isolat serotipe B, dan 3 isolat serotipe C (Chukiatsiri et al., 2012), di China, 29 isolat serotipe A (Feng, 1987; Chen et al.,
1993; Miflin et al., 1997), di Malaysia 10 isolat serotipe A (Zaini dan Iritani, 1992), di Filipina dari 3 isolat masing-masing serotipe A, B, dan C (Nagaoka et al., 1994), dan di Taiwan ditemukan serotipe A (Lin et al., 1994).

Di Indonesia, isolasi $A v$. paragallinarum dilaporkan pada tahun 1975 oleh Sri Poernomo, 1985 oleh Hardjoutomo dan 1987 oleh Sri Poernomo et al., tetapi dari hasil yang didapatkan tidak ada isolat yang dapat dipertahankan sehingga tidak ada informasi mengenai jenis serotipe yang ditemukan (Poernomo et al., 2000). Pada tahun 1991, Takagi et al. melakukan isolasi 3 isolat $A v$. paragallinarum di Indonesia dan ditemukan 2 isolat merupakan serotipe A dan satu isolat serotipe $\mathrm{C}$.

Poernomo et al. (2000), melakukan studi karakterisasi terhadap 18 isolat Av. paragallinarum yang berasal dari jumlah kejadian snot sepanjang tahun 1991-1999 dan mendapatkan hasil sebayak 7 isolat serotipe $\mathrm{A}, 7$ isolat serotipe $\mathrm{C}$ dan 4 isolat serotipe B yang untuk pertama kalinya dilaporkan di Indonesia.

\section{Kesimpulan}

Penelitian ini dapat disimpulkan bahwa tidak 
semua ayam dengan gejala klinis menyerupai snot teridentifikasi bakteri Av. paragallinarum. Sebanyak 4 isolat Av. paragallinarum berhasil diisolasi dari ayam layer yang menunjukkan gejala klinis snot dengan 2 isolat adalah serotipe $\mathrm{B}$ dan 2 isolat adalah serotipe $\mathrm{C}$.

\section{Daftar Pustaka}

Blackall, P. J. (1999). Infectious Coryza: Overview of The Disease and New Diagnostic Option. Clin. Microbiol. Rev. (12):627-632.

Blackall, P. J. and M. Matsumoto. (2003). Infectious Coryza in Diseases of Poultry. $11^{\text {th }}$ Edition. Iowa State University Press. (20): 691-699.

Blackall, P. J., H.Christensen, T. Beckenham, L. L. Blackall, and M. Bisgaard. (2005). Reclassification of Pasteurella gallinarum, [Haemophilus] paragallinarum, Pasteurella avium and Pasteurella volantium as Avibacterium gallinarum gen. nov., comb. nov., Avibacterium paragallinarum comb. nov., Avibacterium avium comb. nov. and Avibacterium volantium comb. Nov. Int. J. Syst. Evol. Microbiol. (55):353-362.

Blackkall, P.J. and E.V. Soriano. (2008). Infectious Coryza And Related Bacterial In: Infections Diseases of Poultry. $12^{\text {th }}$ Edition. Blackwell Publishing. Chapter (20):789-803.

Cabrera, A., V. Morale-Erasto, C. Salqado-Miranda, P. J. Blackall, and V. E. Soriano. (2011). Hemagglutinin Serotyping of Avibacterium paragallinarum Isolates from Equador. Trop. Anim. Health Prod. 43(3):549-51.

Chen, X., P. Zhang, P. J. Blackall, and W. Feng. (1993). Characterization of Haemophilus paragallinarum Isolates From China. Avian Dis. (37):574-576.

Chukiatsiri, K., J. Sasipreeyajan, P. J. Blackall, S. Yuwatanichsampan, and N. Chansiripornchai. (2012). Serovar Identification, Antimicrobial Sensitivity, and Virulence of Avibacterium paragallinarum Isolated From Chikens in Thailand. Avian Dis. 56 (2): 359-64.

Droual, R., A. A. Bickford, B. R. Charlon, G. L. Cooper, and S. E. Channing. (1990).
Infectious Coryza in Meat Chikens in The San Joauqin Valley of California. Avian Dis. (34):1009-1016.

El-Ghany and Abd. W. A. (2011). Evaluation of Autogenous Avibacterium paragallinarum Bacterians in Chikens. Intl. J. of Poultry Sci. 10 (1): 56-61.

El-Sawah, A. M., Soliman, Y. A., and Shafey, S. M. (2012). Molecular Characterization of Avibacterium paragallinarum Strains Used in Evaluation of Coryza Vaccine in Egypt. J. Am. Sci. 8(3):253-263.

Feng, W. (1987). Isolation and Identification of Infectious Coryza Pathogen in Beijing (in Chinese). Microbiol. (China):216-219.

Hardjoutomo, S. (1985). Snot Menular pada Ayam Petelur. I. Wabah Snot Menular pada Peternakan Sambilan di Kabupaten Bogor. Penyakit Hewan (30):13-18.

Lin, J. A., C. L. Shyu, T. Yamaguchi, and M. Takagi. (1994). Characterization and Pathogenicity of Haemophilus paragallinarum Serotipe C in Local Chiken of Taiwan. J. Vet. Med. Sci. (58):1007-1009.

Miflin, J. K., X. Chen, and P. J. Blackall. (1997). Molecular Characterisation of Isolates of Haemophilus paragallinarum from China by Ribotyping. Avian Pathol. (27):119-127.

Page, L. A. (1962). Haemophilus Infections in Chikens: I. Characteristics of 12 Haemophilus Isolates Recovered From Diseases Chikens. Am. J. Vet. Res. (23):8595.

Poernomo, S. (1975). Haemophilus gallinarum pada Ayam: Isolasi Haemophilus gallinarum pada Ayam. Bull LLPH. (8-9):11-22.

Poernomo, S. and P. Ronohardjo. (1987). Efficiacy of Casumix Plus in Broilers With Coryza (Haemophilus paragallinarum Infection). Penyakit Hewan. (19):6-10.

Poernomo, S., Sutarma, M. Raffiee, and P. J. Blackall. (2000). Characterisation of Isolates of Haemohilus paragallinarum from Indonesia. Aus. Vet. J. 78(11):759-62.

Priya, P. M., S. V. Krishna, V. Dineskhumar, and M. Mini. (2012). Isolation and 
Charaecterization of Avibacterium paragallinarum from Ornamental Birds in Thrissur, Kerala. Int. J. Life. Sci. 1(3):87-88.

Roodt, Y. (2009). Towards Unravelling the Genome of Avibacterium paragallinarum. Faculty of Natural and Agricultural Sciences. Departement of Microbial, Biochemical and Food Biotechnology. University of the Free State. Bloemfontein. South Africa.

Sawata, A., K. Kume, and Y. Nakase. (1979). Antigenic Structure and Relationship Between Serotype 1 and 2 of Hemophilus paragallinarum. Am. J. Vet. Res. (41): 14501453.

Tabbu, C. R. (2000). Penyakit Ayam dan Penanggulangannya. Vol. 1. Penerbit Kanisius, Yogyakarta. Pp. 14-20.

Takagi, M., T. Takahashi, and N. Hirayama. (1991). Survey of Infectious Coryza of Chikens in Indonesia. J. Vet. Med. Sci. (53):637-642.
Wahyuni, A.E.T.H., W. Asmara, S. Amanu, T. Untari, H. M. Wibowo, and S. Artanto. (2011). Isolasi dan Identifikasi Haemophilus paragallinarum Penyebab Snott/Koriza pada Unggas. Laporan Penelitian Bagian Mikrobiologi FKH UGM.

Yamaguchi, T., P. J. Blackall, S. Takigami, Y. Iritani and Y. Hayashi. (1990). Pathogenicity and Serovar-Spesific Hemagglutinating Antigens of Haemophilus paragallinarum Serovar B Strain. Av. Dis. (34): 964-968.

Yamamoto, R. (1972). Infectious Coryza. In: Diseases of Poultry, $6^{\text {th }}$ Edition. M. S. Hofstad, B. W. Calnek, C. F. Helmboldt, W. M. Reid, and H. W. Yoder jr (eds). Iowa State University Press: Ames. Iowa. USA Pp: 225-232.

Zaini, M. Z. and Y. Iritani. (1992). Serotyping of Haemophilus paragallinarum in Malaysia. $J$. Vet. Med. Sci. (54):363-365. 